\title{
New Civil-Military Relations and its Research Agendas
}

\author{
Anthony Forster ${ }^{1}$
}

This article argues that the Civil-Military Relations field has been subject to three major challenges which are in the process of dramatically redefining our understanding of how the armed services interact with civilian authorities and more generally with civil society, and indeed how it is studied. First, there has been an epistemological challenge that is developing new understandings in our knowledge. At the outset it is important to highlight the plurality of 'New' Civil-Military Relations methods, rather than a single theoretical approach. A second ontological challenge is leading to new foci of research, as scholars retarget attention on issues that previously we overlooked. Third, there has been a practitioner and policy maker led challenge, which raises a series of new questions which have hitherto been overlooked notably the effectiveness of policy transfer, the need to better understand the changing circumstances in which war is waged, conditions for successful military engagement and the potential role of conditionally in developmental relationships. This article argues that the combination of these three challenges is creating an intellectual revolution in the redefinition of the field of Civil-Military Relations and its parameters, and there are already early signs that these challenges are moving scholars away from an old set of concerns towards a new research agenda. This article argues that the cumulative effect of these changes has the potential to deliver three developments: first, the possibility of applying new knowledge to 'New' empirical and theoretical issues as well as to 'Old' civil-military relations issues; second, enhanced opportunities for interdisciplinary research, with the possibility of combining traditions and theories which have not previously been able to relate to or have been perceived to be in conflict with each other; and third, to root the study of new civil military relations in approaches which have stronger theoretical foundations.

\section{Section One: The Epistemological Challenge to 'Old' Civil-Military Rela- tions}

'Old' Civil-Military Relations research has been dominated by three parallel developments that have been at work since the foundational phase of the field. First

\footnotetext{
${ }^{1}$ Dr Forster is Director of Research, Department of Defence Studies, King's College London at the Joint Services Command and Staff College, United Kingdom. The analysis, opinions and conclusions expressed or implied in this article are those of the author and do not necessarily represent the views of the JSCSC, the UK MOD or any other government agency. Dr Forster is completing a study with Andrew Cottey and Tim Edmunds on the transformation of civilmilitary relations in central and eastern Europe for the ESRC, award number: L213 252009. He is grateful to Doug Bland, Hans Born, Andrew Cottey, Tim Edmunds, Heiner Hanggi, Dan Nelson and Chris Smith for comments on previous drafts of this paper.
} 


\section{THE QUARTERLY JOURNAL}

there has been a strong tradition in much of the Civil-Military Relations literature that has made a virtue of avoiding or making explicit theoretical assumptions, preferring an empirical and often theory-free approach which merely described events and processes and on the basis of deduction, offered generalizations and insights thought this was to some extent less true of scholars like Lucian Pye who located their own work within a set of theoretical issues concerning the role of the military in developing societies (Pye, 1969). ${ }^{2}$

The reasons for the predominance of this type of approach is complex. One explanation may be the nature of texts in the 1950s and 60s in the Civil-Military Relations field, many of which avoided an explicit theoretical dimension. Most of these approaches used descriptive inference offering empirical studies and 'thick' description with generalizations based on the observations typified by some of the work of Janowitz and S.E. Finer (Blondell, 1999:154). As the foundational texts these set the scene for a great deal of subsequent research which took up this atheoretical and problem focused research agenda. Another explanation for a less theoretical focus is the limited interest in theoretical issues amongst key stakeholder groups - the armed forces, policy-makers and practitioners. This particularly affected academics working in military educational institutes who by and large rejected the opportunity to engage in theoretical debates of interest to a wider academic community of scholars, working on similar issues in universities and research institutes. Perhaps too as Douglas Bland argues, CMR in most western states was apparently stable thus providing little reason to move beyond Huntington and others. By not making explicit the theoretical foundations and assumptions upon which scholars based their own analysis, it ghettoized much of the scholarship in the field by cutting it off from wider theoretical debates and developments in knowledge in other social sciences, especially International Relations (IR) and Political Science (PS). Interestingly, Sociology appears less affected by this trend, in part as a consequence of the work of Maurice Janowitz and the work of scholars like Christopher Dandeker, Jacques van Doorn and Bernard Boene who have variously used highly theoretical frameworks for explaining civil-military relations. Perhaps more important was the fact that attempts to avoid theory implicitly relied on theoretical assumptions, notions of causality and a framework of analysis which informed their work, but remained implicit and therefore unexamined precisely because they were not specified.

A second feature of the Civil-Military Relations field is that many IR and PS approaches to Civil-Military Relations have implicitly been rooted in an approach based on analytical realism. In this approach states are conceptualized as cohesive unitary actors, which monopolize relations with the outside world and define the national interest (Carr, 1991; Morgenthau, 1967). Above all they are viewed as

\footnotetext{
${ }^{2}$ This should not be mistaken as an argument that there was not a normative aspect at work especially in relation to the Cold War and agendas as Nicole Ball's work on the security and economy in the third world makes clear.
} 
discrete units and are motivated by a desire to preserve the centrality of states in international relations. Sovereignty is a key element of the realist and neo-realist view, an indivisible commodity attributable to and vigorously defended by states. Governments control a monopoly violence within the state and effective regulation of armed forces is necessary for two reasons: first, to prevent armed forces from interfering in political systems they were created to defend; and second to ensure a state's armed forces served their civilian masters, whether preserving the territorial integrity of a state, deployed abroad in defense of state interests. The dominance of analytical realism drew scholars towards a focus on sovereignty, power and motivations of power maximization. For decades analytical realism has dominated academic analysis of the Civil-Military Relations field, typified by the work of Samuel Huntington, The Solider and the State (1957) and Political Order and Changing Societies (1968) and Samuel Finer, The Man on Horseback: The Role of the Military in Politics (1962).

Perhaps the predominance of this approach reflects the focus on power and military force and the structures within which power was competed for. The prominence of these approaches in Civil-Military Relations might also have been important for what might be termed systemic reasons. In the foundational period of the development of the Civil-Military Relations field, the global struggle between the United States and the Soviet Union, the threat of nuclear war, "hot conflict' and the perceived need for containment, provided a geo-political context in which these approaches appeared to be both theoretically and empirically relevant.

Since 1989 and the end of the Cold War and more particularly the collapse of the Soviet Union in 1991, there have been important theoretical developments which the field of 'Old' Civil-Military Relations can no longer ignore. First the post-positivist, constructivist and normative turn in International Relations, typified by much of the scholarship of Alexander Wendt, Barry Buzan and Ole Waever have offered new contributions to the CMR field (Wendt, 1992:392; Buzan, 1991; Waever, 1996). From an epistemological perspective, post-modernists, critical theorists and social constructivists take issue with the realist and neo-realist scholars and their positivist methodologies. These approaches pose a challenge to what Ngaire Woods terms 'meaning and knowing', by arguing that reality is socially constructed and theories that identify objects and subjects and create hypotheses are therefore questionable. For them, "no category of knowledge is stable enough to yield knowledge' (Woods 1996:25).

Constructivists approaches draw our attention towards many of the hitherto silent assumptions underpinning the realist and neo-realist agenda, especially understanding Civil-Military Relations through a conceptual lens which does not just focus on the use of forces and the pursuit of power. For example, constructivism challenges the unquestioned use of the concepts of national interest, identity formation and sovereignty and reminds us that these are both contested and change- 
able (Norgaard 1994; Jachtenfuchs 1995). In applying the claim that norms and values are socially constructed through intersubjective activity, these approaches draw our attention to the need for a more critical reflection on whose interests are served by the use of a particular constructs, concepts and the prevailing 'conventional wisdom' (Wendt, 1992). At the most critical end of the post-modern spectrum the work feminist scholars like Cynthia Enloe can rightly claim to be intellectual precursors to any future constructivist turn in Civil-Military Relations, but perhaps so too can the new left/dependencia scholars notably Robin Luckham and Mary Kaldor (Luckham, 1971; Kaldor and Asbjorn, 1979). More recently this has drawn attention to the masculinist and modernist epistemologies that underpin many of the dominant theoretical approaches (Zalewski, 1994). For example Zalewski develops a post-positivist argument that it is not enough just to examine a theory on observable evidence alone since 'it is the theory which decides what we can observe' She goes on to suggest '... it is more interesting and illuminating to ask in what way the dominant theories create or construct the empirical realm' (Zalewski, 1994:235).

Applying the methodological insights from this perspective illuminates the tendency to make often arbitrary boundaries defining exclusion zones that often simplify complex issues in an unhelpful way. For example questions concerning civilian control of the armed forces in the Cold War period emphasized 'civilian' rather than 'democratic' control of the military (Cottey, Edmunds Forster, 1999. 'Old' Civil-Military Relations were focused on the threat of praetorian military intervention in domestic politics and the resultant need to enforce civilian executive control of the military. Rarely in the Cold War period was the concept of civilian control linked to notions of democratic control. The division of the world into Western and Soviet camps subordinated a number of issues to a more central question of whether a government was a 'friend' or 'foe.' For example membership of NATO was not conditional upon a particular form of Civil-Military Relations between 1949 and 1989. As Portugal and Turkey and Greece's membership attest, they have had experiences periods of military rule, with NATO membership unaffected. Being a member of the camp was more than a particular form of civil military relations within a state.

More recently constructivist approaches have offered analytical tools for understanding how the concepts of 'civilian control', 'professionalization', 'modernization" and 'security sector reform', have been used as a means to transfer particular western values, ideas and institutions and in some cases weapons Sometimes this is explicit, as with NATOs Membership Action Plans (MAPs) that have explicitly linked acceptance of NATO values to the likelihood of admission. The UK government provides an example of the most explicit form of interaction based on the export of value systems. As a result of the 1997 Strategic Defense Review, the UK government's development of the Defense Diplomacy (DD) Mission.

The aim of UK DD is to dispel hostility, build and maintain trust and assist 
in the development of democratic civilian controlled armed forces. Through bilateral and multilateral programs, the Ministry of Defense is seeking to assist in the development of stable sovereign and democratic states through co-operative military relationships. This activity now covers some twenty-three countries and is supported by a budget of 15 million pounds. The establishment by the Swiss Government of the Geneva based Centre for Democratic Control of Armed Forces is yet another example of the importance attached to the policy transfer of models of Civil-Military Relations, or at the very least value systems. In this respect some have argued that new civil-military relations and old civil-military relations have much in common Some motivations may be seen as altruistic - based on a belief that in offering assistance it will improve the quality of democracy in a recipient state. However, even here a key assumption is often that there are long term self interest in international peace and stability that will have general indirect benefits for the donor countries and in some instances the use of defense assistance is directly linked to defense equipment exports.

One new trend is the application of rational choice approaches to CivilMilitary Relations rooted in positivism. These have drawn on game theoretic approaches to examine issues within the civil-military field. The emergence of rational choice approaches to civil military relations has added a new dimension to the field, of trying to explain civil-military relations, particularly through the work of Peter Feaver, which whatever the limitations of the empirical reach, at least tries to better specify the micro-foundations and assumptions upon which the approach is based (Feaver, forthcoming). Whatever the merits of the rational choice approach and these have been widely debate elsewhere in the disciplines of Political Science and International Relations, this method has given some added weight to a growing interest in 'explaining' issues within Civil-Military Relations. For Smith and Hollis 'understanding' emphasizes narrative whilst the latter offers theory-based explanations. This is more than a matter of semantics with key differences concerning the aspiration to prediction, policy relevance, complexity versus simplicity, and whether scholars should seek to understand single events rather than generalize about classes of events. The growing interest in 'explaining' as a supplement to 'understanding' in the Social Science community has highlighted just how ghettoized the field of 'old' Civil-Military Relations had become in the 1970s and 1980s. At least for some scholars this occurred when cold civil-military relations 'retreated' into US military colleges and focused on mechanistic and legalistic approaches.

A third epistemological development has been the greater demand for multidisciplinarity. Scholars working in the field of 'Old' Civil-Military Relations routinely paid lip service to multi-disciplinary research, but in reality this has often been an absent feature of many Civil-Military Relations studies. In part this can be explained by a sort of intellectual canonization of the field, typical of much of the research. This was driven by the dominance of military sociologists in particu- 
lar areas of the field, notably concerning the relationship between armed services and society and the extent to which the military have the right to be different. Moreover, European scholars have separated themselves from much of the work in North American scholarship, both on theoretical grounds and in terms of the focus of interest. As Douglas Bland notes, many North American scholars have taken a legalistic approach to CMR, whilst in the UK there is a tendency to think in terms of governance (Bland 2001).

This epistemological challenge to the field of 'Old' Civil-Military Relations can be summarized by three propositions: first the atheoretical approach of 'Old' civil relations is now seriously being questioned by greater theoretical rigor in the Social Sciences; second, the dominance of analytical realism is being challenged by new developments in our knowledge especially from the post-positivist theoretical approaches and the normative turn in International Relations rooted in constructivism and distinctively positivist rational choice approaches; third, the ghettoisation of Civil-Military Relations is under serious challenge from outside the traditional field of 'Old' Civil-Military Relations as scholars anchored in different fields of enquiry have engaged in analysis of many issues of direct interest and concern to Civil-Military Relations scholars, scholars of Peace Studies are now more fully engaged with War Studies, scholars working in the field of Development and Transition Studies more engaged in debates and issues of central concern to Civil-Military Relations.

\section{Section Two: The Ontological Challenge}

The epistemological challenge to 'old' CMR has been a feature of recent intellectual developments. However, the ontological challenge - the focus of intellectual enquiry - of much of CMR research is also changing. One of the most striking features of 'Old' civil military relations has been the excessively self-referential debate of most Civil-Military Relations literature, often in the face of declining utility of many of the concepts and ideas which are advanced. Scholars have too often felt obliged to rake over the texts that dominated previous decades to explore new interpretations and offer novel reassessments. Despite the exciting times within which analysts, scholars and practitioners are living, in the last decade the field of Civil-Military Relations field has been remarkably stagnant and few have ventured beyond the agenda set out by the founding fathers. 'Old' Civil-Military Relations has therefore been rather backward looking in terms of its focus of enquiry and remarkably conservative in terms of the issues which have been the focus of its analytical enquiry.

The referent object has often been the state and as a field it remains very statecentric indeed often executive centric, offering a particular ontological focus that disregards a wide range of actors that do not fit in clearly with its assumptions and often ignoring civil society altogether. Perhaps this is understandable when 
the state has greater access to resources to support their militaries than other actors and governments have evolved legal and political instruments to support their claim to use force (Buzan et al, 1998:49). However, one of the most important developments now underway is a growing awareness of the limits of conceptualizing 'the state' as monolithic and unchanging when in most countries the modern state is more often multifaceted and continually evolving.

Another development is an awareness of and interest in questions addressing how the state works have also become far more central in 'New' CMR debates. For example one of the key problems of consolidating democratic control of armed forces lies in the capacity of the state to actually implement its requirements on a day-to-day level. For example Bland argues that the capacity to govern civilmilitary relations is overlooked where the focus is on a narrowly focused rules based approach (Bland 2001). The establishment of institutional procedures and mechanisms for oversight are often necessary but not sufficient conditions if the state's capacity for actually utilizing these procedures is absent (Page, 1992: 174). In part the issue of state capacity has been overlooked because in the foundational phase of Civil-Military Relations, the focus of interest was on regions and states where this issue did not appear to be important, or its salience was masked by factors considered more important, and the link between state capacity and democratization therefore went unmade. In recent transitions literature particularly the work of Linz and Stepan there has been a growing awareness that 'stateness' is a key factor in the process of democratization especially questions concerning weak, contested and failed states (Linz and Stepan, 1998:366; Sorensen, 1993; Holsti, 1996).

In the central and eastern European context but especially in the Former Soviet Union, FRY and Africa, this lack of 'depth' to institutional mechanisms for control is illustrated most particularly in relation to executive implementation and legislative oversight of defense policy (Cottey, Edmunds and Forster 2001). The bureaucracy, in the form of the ministry of defense and the interior ministry is the institutional means though which defense policy is organized, administered and the executive asserts its political authority. In the post-communist context, civilianisation of the bureaucracy has been a central plank of civil-military reforms in many countries. However, this process has also introduced problems related to a lack of expertise. Many new civilian members of the bureaucracy had limited experience of defense and security matters, a situation that directly affects implementation of policy throughout armed forces. These problems have been compounded in states where civil servants are political appointees and who are often prone to be dismissed after a change of government. In these cases, the bureaucracy does not have the opportunity to develop an institutional memory of how its role in the system of democratic control of the armed forces operates. In defense bureaucracies this can routinely frustrate the exercise of legitimate democratic authority in two ways: first, it can make the formulation of policy, and the translation 


\section{THE QUARTERLY JOURNAL}

of that policy into reality problematic: second, it can lead to an over-reliance on the established experience and expertise of the military colleagues.

Legislative oversight of defense policy is also one of the key elements of democratic control over armed forces. In a consolidated representative democracy, it is the legislature that is the institutional expression of popular accountability. Parliaments provide a crucial element of legitimacy to a state's civil-military arrangements. Within a system of democratic control armed forces, the legislature's major role concerns its ability to scrutinize legislation, exercise budgetary control, and prevent policy being enacted without its approval (Page, 1992: 8285). However, for legislative oversight to have real meaning, it is crucial that the will, information and expertise exist for this function to be carried out adequately. These requirements are closely related, and have often been lacking in the postcommunist environment of central and eastern Europe. Here, a particular problem has been a lack of defense and security expertise amongst civilian politicians. This shortage of relevant expertise undermines the process of parliamentary oversight by preventing the 'overseers' carrying out their task effectively. It may prevent them from asking the right questions at a committee stage, or fully understanding the implications of the policies they are reviewing. A similar problem is caused if those that are scrutinizing policy do not have available sufficient information to enable them to make balanced judgments. In the post-communist context, these difficulties can be compounded by the fact that there is often no alternative source of information on defense and security matters in civil-society. In this case, the information provided is likely to contain bias towards the military sector's own institutional interests. As Edward Page notes, in practice the process of legislative scrutiny is a complex bargaining relationship between the legislature and the executive (Page, 1992: 89). If the legislature does not have the ability to enter into this bargaining relationship on appropriate terms, then its ability to oversee policy in anything but the crudest fashion will be limited.

A second and to some extent parallel development to the first is a growing acknowledgement of the inadequate nature and utility of traditional definitions both in terms of the military and civil components of CMR. It has been commonplace in 'Old' CMR to focus exclusively on conventional and uniformed armed forces to the exclusion of 'gray' forces including paramilitaries, intelligence services and forces of an official or unofficial nature that are armed (Cottey, Edmunds and Forster, 2000; Nelson, 2001:5). These have traditionally been excluded from orthodox definitions of the military, though they are often key agents of the state. In many countries typified by Former Yugoslav Republic, Zimbabwe and the Russian Federation, it is the special police and interior ministry troops rather than uniformed members of the armed services which have often been a more pressing concern in ensuring democratic civilian control, than the armed forces per se. In part this preference for a narrow definition has reflected the predominance and application of West European and North American concepts of the 'military' com- 
ponent of Civil-Military Relations. This narrow definition of the armed forces has particularly been encouraged by the work of Huntington in The Soldier and the State which advanced the notions of 'objective' and 'subjective' control explicitly based around the assumption of a clear separation of responsibilities between civil and military sectors, with the military having a clearly defined, autonomous and professionalized area of responsibility concerned with the application and management of force, and civilian authorities in a clearly demarcated and separate zone of authority.

The pioneering work of Moskos, Allen-Williams and Segal on post-modern militaries, explicitly takes issue with this binary bifurcation of the armed forces and civilian authorities (Moskos, Allen-Williams and Segal, 2000). Recent comparative research examining patterns of Civil-Military Relations in central and eastern Europe has also provided strong empirical evidence that in many countries in the region 'special' police, paramilitary organizations and interior ministry troops are important elements of the wider security sector, often accountable to different ministries within government and governed by different legislative and financial regulations (Cottey, Edmunds and Forster, 2001). Many scholars from the field of Development Studies have been at the forefront of arguing that our analytical net needs to be more widely cast in terms of security sector reform to explicitly include militarized forces as well as the military per se. For example Nicole Ball has argued that a better means of conceptualizing the military aspect of Civil-Military Relations is to use the concept of 'security family.' This includes the security forces armed forces, policy, paramilitaries and intelligence services as well as informal security forces (Ball, 2001:47).

A third and well-documented development has come from the collapse of the Soviet Union, the end of the Cold War and the challenge posed by what Francis Fukuyama terms the end of ideologies. This has closely linked military reform with the process of democratization. Perhaps most starkly, scholars analyzing 'failed states' like Sierra Leone and Somalia, suggest that the absence of any institutions, bureaucracy and administration and the rule of law are central to understanding Civil-Military relations in these states. For some like Chris Smith reform of militaries is in fact dependent upon a more general processes of developing effective democracy especially in countries such as Nigeria and Indonesia '.... where Civil-Military Relations lie at the heart of democratization and the development of state legitimacy' (Smith, 2001:11). This is particularly the case in the core areas of Civil-Military Relations, especially democratic civilian control of armed forces. Dan Nelson has further argued that one of the aspects is a growing interest in the presence or otherwise of what might be termed civil society (Nelson, 1998). A further aspect of this is the link between civil-society, nationhood and liberal democracy. Taras Kuzio argues that in many instances 'there are few commonly held values that underpin the overarching societal culture of the newly emerging political community' (Kuzio, 2001:171). Nationalism is therefore 
intimately connected to the development of politics, administration and the means of coercion. This opens up a potentially fruitful dialogue with scholars of nationalism, democratic transition and democratization that amongst the Civil-Military Relations scholarly community has been largely absent (Nelson, 2001).

A fourth notable change is a greater awareness of non-state based challenges to Civil-Military Relations typified at one end of the spectrum by the work of Barry Buzan and Ole Waever and the concept of securitisation theory - the discursive processes through which social groups label something as a threat (Buzan, 1991; Buzan et al 1998). The application of this concept has the power to reconceptualize whose security we should concerned with which parallels the participatory appraisal process that is now being used to calibrate actually existing security. Challenging the orthodox and state centric view of 'Old' Civil-Military Relations, this approach places individuals and communities at the center of its concern. The contribution of securitisation theory to 'New' Civil-Military Relations is that is alerts us to three issues: first, what are termed referent objects, things that are said to be existentially threatened and that have a legitimate claim to survival; second, securitisation actors - who affect the dynamics of a sector by declaring something a referent object - existentially threatened; and third functional actors who affect the dynamic of a sector without being the referent object or a securitising actor (Buzan et al, 1998:36). This analytical approach therefore provides an important intellectual bridgehead between 'Old' Civil-Military Relations and those interested in Security Sector Reform.

A fifth trend is a growing awareness of the need to better understand the interaction between structures and agents. Typical of much of the 'Old' Civil-Military Relations was a rather static view of the field. The focus was often on structural aspects of CMR especially constitutions and the way in which they shaped the arenas in which power was competed over. Some scholars took an agency-based approach exploring the interests of the military, but often it has to be noted these were limited to examining them as a special type of interest group. In research based on the Transformation of Civil-Military Relations ESRC project, Cottey, Edmunds and Forster have argued that there is a need for a more inclusive approach to analyzing Civil-Military Relations, especially the need to examine what they term a 'second generation' set of problems, especially in central and eastern Europe (Cottey, Edmund and Forster 2000). This approach is interested in the interaction between structures and agents, the need to explore attitudes and behavior of key actors as well as constitutions and institutional design of those engaged in Civil-Military Relationships. In a similar vein Daniel Nelson argues that the 'relations' component of Civil-Military Relations has too often been overlooked and there is a need to better understand the interactive element of CMR (Nelson, 2001).

What is clear from is that there has been an important convergence on what has been termed 'the security sector.' Whether as Chris Smith argues the cause 
is the 'introduction of a development standpoint into contemporary discourse on Civil-Military Relations' (C. Smith, 2001:9) or as is suggested here the epistemological and ontological developments in and around the Civil-Military Relations field, is clearly contested. What is beyond doubt is that the convergence has led to a burgeoning dialogue between CMR scholars and those working in the field Peace Studies and particularly Development Studies - and perhaps one that might become more fruitful than that triggered by the neo-Marxist attack on 'Old' Civil Military relations which came from development studies. This has also had a resonance in the administrative organization of policy-making. It is the Secretary of State for International Development rather than the Defense of Foreign Secretary who chairs the Whitehall cross-departmental initiative on conflict prevention one organizational indicator of what might be termed the 'DFID-isation' or 'developmentalisation' of a key part of the Civil-Military Relations field. Moreover the European Commission has been at the forefront of arguing for what might be termed an inclusive or holistic approach to conflict prevention, which draws together military, political and economic instruments of influence and which the European Commission considers the EU ideally suited to take the lead. The European Commission, a self-proclaimed civilian power organization, has also set out its interest in conflict prevention claiming that '[I]ndividual countries are unable to address these problems on their own or through the classic instruments of bilateral diplomacy' (CEC, 2001).

\section{Section Three: The Policy Challenge}

The end of the Cold war has had a dramatic effect on the CMR field in a number of ways. First and foremost has been a move towards encouraging states to embrace liberal democratic states to underpin international peace and stability. As Nicole Ball points out, during the Cold War Western governments provided significant amounts of aid to allies without paying much attention to or caring whether its Civil-Military Relations were based on democratic principles (Ball, 2001:46). In many cases fighting communism was the most important issue in offering aid. However, with the end of the Cold War there has been a renewed interest in political conditionality and especially the objective of promoting democratic civilian control or armed forces and effective management of the security sector. Indeed for some governments this has become a primary objective of aid and development programs. In the UK the objective of Defense Diplomacy was the centerpiece of the 1997-8 Strategic Defense Review. It set as a key mission of the armed forces 'dispelling hostility, building and maintain trust and assisting in the development of democratically accountable armed forces.' In Australia the government's Strategic Policy 97 (ASP 97) task is to offer a '... military strategy for shaping the strategic environment through international engagement. In Switzerland the creation of a new Centre in Geneva (alongside the Centre for Security Policy and the Centre for Humanitarian De-mining) for the Democratic 
control of Armed Forces with the aim of actively contributing to and promoting the concept of democratic control of armed forces.

These public policy initiatives have raised important questions concerning the appropriate role for the armed forces in peacetime conflict prevention activities as too has the 'war on terrorism' in the aftermath of the 11 September attacks in the US. One set of questions concerns the distribution of effort between preparing for, and fighting in conflicts, and activities designed to prevent conflict in the first place. A second set of questions concerns the relationship of uniformed personnel with colleagues from the development and international aid communities. A crucial issue here is the need to further explore where the added value or a distinctive contribution can be made from each community that is both efficient and effective. A third set of questions concerns the role, utility of military force and nature of warfare in advanced liberal democratic societies. Interestingly at this moment in time, new policy thinking does not have much connection with current academic discourse or indeed any emerging paradigm shift.

Within the broad area of conflict prevention budgets have expanded over the last decade, without a parallel investment in developing methods for understanding how and why particular policies work. More recently as budgets have begun to stabilize and in some cases to shrink, treasury and finance departments have begun to question why certain activities have been undertaken, what basis information has been used to inform policy decisions and how this information has been used to inform future strategy planning. The absence of any clear conceptual tools for analyzing the links between objectives, the methods of delivery and the outcomes to be achieved posed important questions for the Social Science and Public Policy community. In the defense community in general there was little evaluation of either the effectiveness or efficiency of what we now term Defense Diplomacy. By contrast in the International Development community, programs were quite rigorously evaluated against specific micro objectives, but the linkage to macro or meso objectives often went unmade.

One reasons for an interest in 'New' CMR is the challenge posed by governments policy-makers and practitioners in central and eastern Europe that continue to ask the question 'never mind the theory, does it work in practice?' thus forcing much greater reflection on the link between theory and practice and what works and why. Another pressing need to better understand the policy dimension of 'New' Civil-Military Relations is the need to deconflict activities with other allies. This has become increasingly important as recipient countries complain of excessive and unhelpful duplication and competition. Western interest in conditionality has been further reinforced by the self-generated aspiration of many post-communist sates in central and eastern Europe to join western institutions especially NATO and the European Union. This has led to a shared interest in West and eastern Europe concerning the circumstances under which effective policy transfer can take place. 
The cumulative effect of these developments is to reinvigorate the policy dimension of CMR which was always present in 'Old' CMR, but which more often than not was either overlooked or interpreted as the crude application of one state's model of Civil-Military Relations on another state. This opens up exciting possibilities for greater and more serious engagement with scholars and practitioners working in the field of public policy.

\section{Section Four: The New Research Agenda}

There are a least five main areas of work which provide a starting point to think about where lines of enquiry might be pursued and a new set of research priorities developed.

1. There is a real need to stop raking over the works of old masters and need to break out of the self-imposed constraints of 'Old' CMR. In particular there is a need to make theoretical problems clearer and more explicit. There is also a need better link them to IR, Political Science and Sociological theories. In particular there needs to be greater core theoretical debates about the nature of Civil-Military Relations which as has been argued above has quite weak theoretical foundations. Key issues here are:

a. How concepts are constructed and deconstructed (critical theory and the constructivist turn provide potentially rich analytical purchase).

b. The role of institutions, rules and norms (regime theory and institutionalist approaches).

c. The interplay between institutions and actors, especially the tension between principal actors, MODs, militaries and public servants and politicians.

2. The need for a better understanding of the holistic nature of conflict prevention. Key issues here are:

a. The link between a range of activities: Defense Diplomacy, Security Sector Reform and International Development.

b. The added value of each of these policy instruments in addressing conflict prevention.

3. The relationship between national, sub-national and international levels of Civil-Military Relations system.

a. To what extent can external actors and ideas shape internal CivilMilitary Relationships? The interaction of states, actors and individuals in adapting to norms and rules advanced by 'international society.' 
b. To what extent does a convergence on particular principles or organizational methods become so dominant that they become an instrument of international society, e.g., Western notions of democratic civilian control or professionalization?

c. What are the tensions between national, sub-national and international levels of Civil-Military Relations? Much of the literature assumes that there is a recognizable European model of Civil-Military Relations and discounts other models. Clearly there is a need for research that explores different non-western forms of Civil-Military Relations to explore the nature of these in relation to other regional and European forms.

d. The democratic peace thesis suggests war is less likely. How does this affect Civil-Military Relations?

e. The role of international society. Important issues to explore are: whether common values shaping Civil-Military Relations and the role of international society in shaping Civil-Military Relations?

4. The classification of different types of Civil-Military Relations. Some work on this has already been undertaken through work of existing research teams but there is a need to organize new teams around common theoretical approaches and examples.

a. This needs to include deep study and thick description of national examples as well as comparative work.

b. This work needs to be global and regional in nature, with particular attention on the forgotten and the difficult regions of the World.

c. Comparative work needs to be much more theoretically focused.

5. How does the changing nature of the state affect Civil-Military Relations and various conditions, peace, crisis, and war especially post 11 September? Key issues here are:

a. How do different types of state (weak/strong/failed or failing) affect Civil-Military Relations?

b. Are states adapting the use of armed forces as policy instruments and if so how?

c. Are states changing the nature of regulation of Civil-Military Relations?

d. What are the new dynamics of waging a global war on terrorism? 
6. Finally, do we know how and why effective policy transfer takes place and the key determinants in this process.

\section{Conclusions}

This article argues that there is now a range of challenges to the way in which 'Old' Civil-Military Relations has been conceptualized that requires a major transformation of the field into what is termed here 'New' Civil-Military Relations. These challenges come from three areas: an epistemological challenge which is opening up new ways of explaining and understanding CMR; an ontological challenge changing the focus of our attention from a state centric approach to one which is far more inclusive; and finally a strong public policy challenge focusing our attention on issues of effectiveness and efficiency in public policy delivery and policy transfer. The impact of these changes are: first, a greater need for theoretical rigor; second, a need to supplement the existing Civil-Military Relations focus of enquiry with new issues of interest; and third, the need for Civil-Military Relations scholars to embrace an interdisciplinary approach drawing on cognate disciplines. In this endeavor we should not lose site of important knowledge gained in the period of 'Old' Civil-military relations nor of the plurality of methodological approaches required to explain and understand 'New' civil-military relations and its research agendas.

\section{References}

Ball, Nicole (2001) 'Transforming security sectors: the IMF and World Bank Approaches', Conflict, Security Development, 1:1, 45-66.

Bland, Douglas (2001) 'Patterns in Liberal democratic Civil-Military Relations', Armed Forces and Society, Summer 27:4, pp.525-540.

Blondell, Jean. (1997) 'Then and Now: Comparative Politics', Political Studies, XLVII, $152-160$

Buzan, Barry. (1991) People, States and Fear: An Agenda for International Security Studies in the Post-Cold war Era, Hemel Hempstead: Harvester-Wheatsheaf.

Buzan, Barry, Waever, Ole and de Wilde, Jaap. (1998) Security: A New Framework for Analysis, London: Lynne Rienner.

Commission of the European Communities (2001) Communication from the European Commission on Conflict Prevention, (COM (2001)211 final, 11 April 2001.

Cottey, Andrew, Edmunds, Tim and Forster, Anthony (1999) ，'Democratic Control of Armed Forces in Central and Eastern Europe'; A Framework for Understanding Civil-Military relations in Postcommunist Europe, ESRC "One Europe or Several?” Working paper 1/99 (Sussex: University of Sussex). 
THE QUARTERLY JOURNAL

Cottey, Andrew, Edmunds, Tim and Forster, Anthony. (2000) 'The Second Generation Problematic: Rethinking Democratic Control of Armed Forces in Central and Eastern Europe', Transformation of Civil-Military Relations Paper 1.7, December 2000.

Cottey, Andrew, Edmunds, Tim and Forster, Anthony. (2001) Democratic Control of Armed Forces in Central and eastern Europe: Guarding the Guards, Basingstoke: Palgrave.

Carr, E. H. (1991) The Twenty Years Crisis, 1919-1939: An Introduction to the study of International Relations, (London: Macmillan) second edition.

Feaver, Peter (forthcoming) Armed Servants: Agency Oversight and Civil Military Relations, Harvard University Press.

Fukuyama, Francis. (1992) The End of History and the Last Man, London: Penguin.

Holsti, K.J. (1996) War and the state of war, Cambridge: Cambridge University Press, Studies in International Relations, 51.

Jachtenfuchs, Markus. (1995) 'European Governance', European Law Journal, 1, 2, 115-32.

John J Mearsheimer (1990) 'Back to the Future: Instability in Europe after the Cold war', International Security, 15:1, summer, 5-56.

Kaldor, Mary Asbjorn, Eide, ed. (1979) The World Military Order: The impact of military technology on the Third World, London Macmillan Press.

Kuzio, Taras. (2001) 'Transition in Post-Communist States: Triple or Quadruple?', Politics, 21:3, 168-173.

Luckham, Robin (1971) The Nigerian Military: a sociological analysis of authority \& revolt, 1960-67, Cambridge, Mass: Harvard University Press.

Moskos, Charles, Allen Williams, John and Segal, David. (2000) Post Modern Militaries.

Nelson, Daniel, N. (1998) 'Civil Armies, Civil Societies', Armed Forces and Society, 26:1, Fall, 136-158.

Nelson, Daniel, N. (2001) Definition, Diagnosis, Therapy - A Civil/Military Critique, unpublished paper

Norgaard, A. (1994) 'Institutions and Post Modernity', Co-operation and Conflict, 29,3, 245-87.

Page Edward C. (1992) Political authority and bureaucratic power: a comparative analysis, London: Harvester Wheatsheaf.

Pye, Lucian (1969) Guerrilla Communism in Malaya: Its Social and Political Meaning, Cambridge, Mass. MIT press.

Smith, Chris, 'Security-sector reform: development breakthrough or institutional engineering?', Conflict Security Development, 1:1, 2001, 5-19.

Sorensen, Georg (1993) Democracy and Democratization, Colorado: Westview Press. 
Waever, Ole (1996) 'European Security Identities', Journal of Common Market Studies, 34:1, 103-32.

Wendt, Alexander. (1992) 'Anarchy is what the state makes of it: the social construction of power politics', International Organization, 46, 2.

Woods, Ngaire. (1996) 'The Uses of Theory in the Study of International Relations' in Woods, Ngaire. ed. Explaining International Relations since 1945, Oxford: Oxford University Press, 9-31.

Zalewski, Marysia (1994) in Carlsnaes, Walter \& Smith, Steve, eds., European foreign policy: the EC and changing perspectives in Europe London: Sage. 